\title{
Transaction Costs and Recorded Remittances in the Post-Soviet Economies: Evidence from a New Dataset on Bilateral Flows*
}

\author{
Jakhongir Kakhkharov \\ Department of Accounting, Finance, and Economics, Griffith University, 170 Kessels Road, \\ Nathan Qld 4111, Australia Email: j.kakhkharov@griffith.edu.au \\ Alexandr Akimov \\ Department of Accounting, Finance, and Economics, Griffith University, Parklands Drive, \\ Southport, Qld, 4222, Australia Email: a.akimov@griffith.edu.au \\ Nicholas Rohde \\ Department of Accounting, Finance, and Economics, Griffith University, Parklands Drive, \\ Southport, Qld, 4222, Australia Email: n.rohde@griffith.edu.au
}

JEL classification: F21; F22; F30; P33

Keywords: Remittances; Migration; Money transfer fees; Transition; Post-communist

\footnotetext{
*The authors thank the Central Bank of the Russian Federation as well as the Federal State Statistics Service (Rosstat) of the Russian Federation for providing statistical data for this research. We are grateful to the editor as well as two anonymous referees for their valuable suggestions and comments.
} 


\section{Introduction}

The phenomenal increase in the flow of remittances to transition economies and developing countries has raised questions about the role of remittances in various types of economic activity. For many households, the main purpose of remittances has been to smooth consumption and alleviate budget constraints. However, the financial system and entrepreneurship also appear to be immediate beneficiaries of this windfall (Aggarwal et al. 2011; Chowdhury 2011).

The large-scale remittances in the post-Communist economies are a relatively recent phenomenon and are linked to dramatically increased labour mobility since the collapse of the Berlin Wall. As a result, the research on remittances in transition economies remains scarce, albeit growing rapidly. The main objective of this research is to investigate the determinants of remittances using newly available data covering the countries of the former Soviet Union. Focusing on this region allows the use of data which was not available for previous studies of remittances. Data on annual bilateral transfers from Russia to the countries of remittance recipients, data on the annual flows of migrants from particular countries to Russia, annual data on the number of branches of money transfer operators (MTOs) in Russia, and statistics on remittance transfer fees ${ }^{1}$ charged by MTOs are all novel variables used in this panel study. Despite a somewhat small sample size, the results appear to be robust and provide solid empirical evidence as to the determinants of remittances. Remittances flow to less-developed countries via formal and informal channels. In the case of the former Soviet Union, the formal channels predominantly consist of bank and MTO

\footnotetext{
${ }^{1}$ Remittance transfer fees are the service fees charged by MTOs and are considered as transaction costs for remitting money.
} 
transfers. Informal channels include cash carried by migrants and third parties ${ }^{2}$ (friends, relatives, and other couriers), as well as transfers similar to 'hawala' ${ }^{3}$. It is assumed that the higher the proportion of remittances through formal channels, the greater the expected benefits of remittances to the economy as a whole. The financial system stands to gain from remittance transfer fees. Moreover, if it is sufficiently effective, it may attract new deposits from the beneficiaries of these transfers. Furthermore, channelling remittances through official channels, typically catalysed by lower remittance transfer fees, renders them subject to monitoring to deter money laundering and the financing of terrorist activities.

Many factors may impact upon the flow of remittances. The regulatory framework for transferring remittances, taxation considerations, and the foreign exchange regimes in the host and home countries of migrants, are among the factors that may affect the recorded remittances. However, one of the main findings of this study is that lower transaction costs facilitated an increase in the volume of remittances passing through official channels.

The paper is organized as follows. Section 2 briefly reviews the literature on the determinants of remittances. Section 3 presents an overview of migration flows and remittances in the post-Soviet transition economies. Section 4 provides a description of the data and the methodology used. Section 5 presents the estimation results, and discusses the major findings and their implications. Finally, Section 6 draws conclusions and makes some policy recommendations.

\footnotetext{
${ }^{2}$ All travellers departing Russia are required to report any currency and/or traveller's cheques of US\$10,000 or more, or a foreign currency equivalent that they are carrying. Although this seems to be a factor discouraging the use of informal channels for large transfers, the majority of recorded transfers from Russia are for small amounts.

${ }^{3}$ Hawala is an alternative informal transfer method used in parallel to official channels and implies the use of brokers (hawaladars), family and regional ties and connections.
} 


\section{Determinants of Remittances: Theoretical Debate and International Evidence}

The theoretical foundations of micro-level research on the determinants of remittances were laid down by Lucas and Stark (1985), who identified a number of determinants at the household level: 'pure altruism', 'pure self-interest', and 'tempered altruism or enlightened self-interest'. However, in many cases the different motives could account for the same type of migration and remittance behaviours. While a body of research has attempted to identify these distinct motives, the process is difficult given that survey data is not always appropriately detailed.

Classical and neo-classical economic models view migrants as self-interested agents who leave their places of origin in search of new economic opportunities in their destination countries. As such, migrant remittances represent the largest observable impact of migration on migrant sending areas. The New Economics of Labour Migration (NELM), developed by Stark (1991) and others, links remittance behaviour to migration decisions. According to the NELM, migration decisions are a 'calculated strategy' of households aimed at improving the well-being of the whole family, and not an 'act of desperation or boundless optimism' (Stark 1996, p. 26). According to the NELM, by sending a member of a household to migrate, the household aims to maximize joint income and status, and minimize risks. Thus the NELM offers another important insight into migration decisions by linking labour migration with public policy and capital market failures in the labour-source countries. In making the decision on migration, households design their own strategy to cope with the absence of appropriate credit, insurance instruments and public protection. Remittances from a family member abroad provide an additional source of funding, insurance in case the main source of family income falters, and financial protection in case of a rainy day. As such, migration can be viewed as a result of risk aversion on the part of a household that has insufficient income. 
In general, the NELM has proved to be an innovative, realistic, useful and widely applied framework in recent migration studies.

Some critics of the NELM, such as Hagen-Zanker (2010), highlight its strong assumptions of rationality, and others, such as Aslan (2011), criticize NELM for its neglect of the role of informal institutions as non-rational and non-economic determinants of human motivation and behaviour. In the context of the former Soviet Union, and especially in Central Asia, these informal institutions and social networks seem to play a significant role in migration decisions (Aslan 2011; Juraev 2012).

Another theoretical model emphasizes the exchange motive in remittance behaviour (Cox and Jakubson 1995; Rapoport and Docquier 2006): remittances can be used to pay for services provided by relatives in the home countries of migrants. Modern empirical studies exploring determinants of remittances may be divided conceptually into two categories. On the one hand, micro-level research uses household-level surveys to investigate the remittance decisions of individuals. On the other, macro-level inquiries resort to macroeconomic indicators to understand determinants of remittances in the economy as a whole.

The main focus of this paper is on macroeconomic determinants. Macro-level research has identified a number of factors which have influenced the amount of remittances a country receives. Among these are differences between the host and home countries in the group of macroeconomic variables, such as relative income/wage levels, economic growth, interest rates, macroeconomic stability, and variations in business cycles. There are also a number of other macroeconomic factors which could be considered on a stand-alone basis or in relation to their dynamics in both host and home countries, such as exchange rate-related variables (e.g. fluctuations, dual exchange rate systems, restrictions, existence of a foreign exchange black market), political risk and institutional development, unemployment, 
demographics, the infrastructure for fund transfers, the business environment and financial sector development.

There is also a strand in the literature on determinants of remittances which includes demographic/social factors (e.g. age dependency, illiteracy, percentage of population under 14 years old, income inequality) and combines micro and macro factors into a model (Adams 2009; Buch and Kuckulenz 2010). These demographic/social factors include the number of children in a family; the dependency ratio, and the ratio of females in the population of the host country, as well as among the migrants themselves.

A summary of empirical literature on the determinants of remittances is presented in Table 1. 
Table 1. A summary of empirical literature on the determinants of remittances

Author (s) Method $\quad$ Data

Findings

\begin{tabular}{|c|c|c|c|}
\hline $\begin{array}{l}\text { Ahamada and Coulibaly } \\
\text { (2011) }\end{array}$ & Panel data techniques & $\begin{array}{l}87 \text { emerging and developing } \\
\text { countries }\end{array}$ & $\begin{array}{l}\text { A high level of financial development in remittance recipient countries } \\
\text { allows remittances to have a stabilizing effect on GDP growth. }\end{array}$ \\
\hline Al Mamun et al. (2015) & Panel data techniques & $\begin{array}{l}61 \text { top remittance recipient } \\
\text { countries }\end{array}$ & $\begin{array}{l}\text { A positive relationship between remittances and labour productivity in both } \\
\text { higher remittance (size) and remittance share of GDP. }\end{array}$ \\
\hline Alkhathlan (2013) & $\begin{array}{l}\text { Autoregressive } \\
\text { distributed lag }\end{array}$ & Saudi Arabia & $\begin{array}{l}\text { Significant negative correlation between workers' remittances and economic } \\
\text { growth in the short term. }\end{array}$ \\
\hline Aydas et al. (2005) & $\begin{array}{l}\text { Ordinary least } \\
\text { squares (OLS) }\end{array}$ & Turkey & $\begin{array}{l}\text { Black market premium, interest rate differential, inflation rate, growth, } \\
\text { home and host country income levels, and periods of military administration } \\
\text { in Turkey have significantly affected remittances. }\end{array}$ \\
\hline Bang et al. (2016) & $\begin{array}{l}\text { An instrumental } \\
\text { variable quantile } \\
\text { regression }\end{array}$ & Kenya & $\begin{array}{l}\text { While remittances increase expenditure at all levels of the distribution, the } \\
\text { impact is greatest for poorer households. }\end{array}$ \\
\hline Bouhga-Hagbe (2006) & $\begin{array}{l}\text { Vector error } \\
\text { correction model }\end{array}$ & $\begin{array}{l}\text { Egypt, Jordan, Morocco, } \\
\text { Pakistan and Tunisia }\end{array}$ & $\begin{array}{l}\text { Altruism could be an important factor in the flow of remittances. Hardship } \\
\text { increases remittances. }\end{array}$ \\
\hline Coulibaly (2015) & $\begin{array}{l}\text { Panel Granger } \\
\text { causality tests based } \\
\text { on Seemingly } \\
\text { Unrelated } \\
\text { Regressions }\end{array}$ & $\begin{array}{l}\text { Sub-Saharan African } \\
\text { countries. }\end{array}$ & $\begin{array}{l}\text { There is no strong evidence supporting the view that remittances promote } \\
\text { financial development in SSA countries. }\end{array}$ \\
\hline Durand et al. (1996) & OLS, Bivariate probit & Mexico & $\begin{array}{l}\text { Migrants are more likely to send remittances to entrepreneurially vibrant } \\
\text { communities. }\end{array}$ \\
\hline $\begin{array}{l}\text { Freund and Spatafora } \\
\text { (2008) }\end{array}$ & $\begin{array}{l}\text { Cross-country panel } \\
\text { regressions }\end{array}$ & 104 countries & $\begin{array}{l}\text { Flow of migrants was the primary determinant of official remittances; } \\
\text { transaction costs are also important. }\end{array}$ \\
\hline Hagen-Zanker (2010) & Tobit models & Moldova & Self-insurance and loan repayment motives drive the volume of remittances. \\
\hline
\end{tabular}




\begin{tabular}{|c|c|c|c|}
\hline Author (s) & Method & Data & Findings \\
\hline $\begin{array}{l}\text { Hathroubi and Chaker } \\
\text { (2016) }\end{array}$ & $\begin{array}{l}\text { Wavelet methods to } \\
\text { time series analysis }\end{array}$ & Saudi Arabia & $\begin{array}{l}\text { Remittance outflows are strongly associated with the host country } \\
\text { aggregates and their relationships change across time scale/frequency bands. }\end{array}$ \\
\hline $\begin{array}{l}\text { International Monetary } \\
\text { Fund (2005) }\end{array}$ & Panel data techniques & 101 countries & $\begin{array}{l}\text { The high cost of remittances and a non-conducive business environment in } \\
\text { the home country may have detrimental consequences and result in lost } \\
\text { opportunities for home countries. }\end{array}$ \\
\hline $\begin{array}{l}\text { Lueth and Ruiz-Arranz } \\
\text { (2008) }\end{array}$ & $\begin{array}{l}\text { Cross-country panel } \\
\text { regressions }\end{array}$ & $\begin{array}{l}11 \text { countries from Asia, } \\
\text { Europe and the Middle East }\end{array}$ & Evidence of links between remittances and business cycles. \\
\hline Piracha and Saraogi (2012) & $\begin{array}{l}\text { Two-part Heckman } \\
\text { selection model }\end{array}$ & Moldova & $\begin{array}{l}\text { A combination of household and migrant characteristics and some } \\
\text { community-level variables are the key elements in explaining remittance } \\
\text { behaviour. Altruistic and investment motives drive remittances. }\end{array}$ \\
\hline $\begin{array}{l}\text { Schiopu and Siegfried } \\
\text { (2006) }\end{array}$ & $\begin{array}{l}\text { Cross-country panel } \\
\text { regressions }\end{array}$ & 7 EU neighbouring countries & $\begin{array}{l}\text { Transaction costs, proxied by remittance infrastructure, do not have a } \\
\text { significant impact on remittances in the whole sample and are significant } \\
\text { only for remittance flows between countries without common borders. }\end{array}$ \\
\hline Schrooten (2005) & $\begin{array}{l}\text { Generalized method } \\
\text { of moments (GMM) }\end{array}$ & $\begin{array}{l}\text { Eastern Europe and the } \\
\text { Commonwealth of } \\
\text { Independent States }\end{array}$ & $\begin{array}{l}\text { In Eastern Europe, remittances increase with unemployment and the size of } \\
\text { the interest rate differential, and are inversely related to domestic credit. }\end{array}$ \\
\hline Schrooten (2006) & GMM & Former Soviet Union & $\begin{array}{l}\text { The performance of the domestic banking sector and the access of the } \\
\text { private sector to credit are important determinants of remittances. Better } \\
\text { international integration and quality of institutions lead to an increase in } \\
\text { remittances. }\end{array}$ \\
\hline Straubhaar (1986) & OLS & Turkey & $\begin{array}{l}\text { Turkish emigrants are not sensitive to economic benefits of remitting more. } \\
\text { Positive link between political stability in home countries and remittances. }\end{array}$ \\
\hline $\begin{array}{l}\text { Vargas-Silva and Huang } \\
\text { (2006) }\end{array}$ & $\begin{array}{l}\text { Vector error } \\
\text { correction model }\end{array}$ & $\begin{array}{l}\text { Brazil, Colombia, } \\
\text { Dominican Republic, El } \\
\text { Salvador, Mexico and USA }\end{array}$ & Host country (USA) conditions are more important than home country. \\
\hline
\end{tabular}


In summary, the literature on the determinants of remittances in various regions is not conclusive. This is due to the fact that the remittance decision is complex, depending on status, education, intentions, gender, family ties, age, and many other characteristics. It could also be due to an endogeneity problem and/or the uniqueness of each region/country. However, this uniqueness should not preclude cross-country examination of the determinants of remittances. In fact, one of the remarkable shortcomings of literature on the determinants of remittances is the limited availability of panel studies on groupings of countries with similar characteristics. The present research addresses this gap in the literature by investigating the determinants of remittances in a set of countries with similar economic histories, commonly used language, and significant cultural ties.

\section{Overview of Remittances within the Former Soviet Union}

The analysis in this paper focuses on the determinants of remittances flowing from the Russian Federation to the rest of the former Soviet republics. Some of these former Soviet countries are among the world's leaders in terms of remittances to GDP ratios. In fact, four (indicated in bold type) of the world's top remittance recipients, measured in these terms and shown in Table 2, are located in this region. 
Table 2. Top Recipients of Personal Remittances in the World in 2014

\begin{tabular}{lrrc}
\hline Country & $\begin{array}{c}\text { Remittances } \\
\text { (US\$ million) }\end{array}$ & $\begin{array}{c}\text { GDP } \\
\text { (US\$ million) }\end{array}$ & $\begin{array}{c}\text { Remittances to } \\
\text { GDP ratio (\%) }\end{array}$ \\
\hline Tajikistan & 3,835 & 9,241 & 41.4 \\
Kyrgyz Republic & 2,246 & 7,404 & 30.3 \\
Nepal & 5,875 & 19,636 & 29.9 \\
Tonga & 114 & 434 & 26.3 \\
Moldova & 1,981 & 7,944 & 24.9 \\
Lesotho & 456 & 2,088 & 21.8 \\
Armenia & 2,159 & 10,882 & 19.8 \\
Lebanon & 8,899 & 45,731 & 19.5 \\
Honduras & 3,329 & 19,385 & 17.7 \\
\hline
\end{tabular}

Source: Calculations of the author based on data for bilateral remittances (World Bank 2014b) and GDP data from World Development Indicators

As is evident from Table 3 below, the proportion of remittances from Russia among the total remittances received by countries included in the estimations of this study varies significantly between countries, from $11 \%$ to $100 \%$. This is the case despite large differences in the post-Soviet transition path of these economies.

Given that the Baltic states (Estonia, Latvia and Lithuania) have some structural differences with the rest of our sample, their inclusion requires some justification. These countries joined the European Union in 2004, which may have altered the migration trajectories to and from the region. For this reason, the determinants and patterns of remittances in the Baltics could be hypothesized to differ from the rest of the former Soviet countries. However, a review of World Bank (2014) statistics on bilateral remittances indicates that the Russian Federation still remains the major source of remittances for these countries. Russia is the main source of remittances for both Estonia (US\$137 million) and Latvia (US\$193 million), significantly outstripping the second most important sources: Finland in the case of Estonia (US\$87 million), and the UK in the case of Latvia (US\$165 million). Lithuania is the only country in the Baltics where Russia, with US\$269 million in 
remittances, is ranked only second as a source of remittances behind the principal country, the UK (US\$547 million).

Table 3. Proportion of Remittances from Russia and relative to GDP for the Former Soviet Republics in $2014^{4}$

\begin{tabular}{lrrcc}
\hline Country & $\begin{array}{c}\text { Total } \\
\text { remittances } \\
\text { (US\$ million) }\end{array}$ & $\begin{array}{c}\text { Remittances } \\
\text { from Russia } \\
\text { (US\$ million) }\end{array}$ & $\begin{array}{c}\text { Proportion of } \\
\text { remittances from } \\
\text { Russia (\%) }\end{array}$ & $\begin{array}{c}\text { Remittances to } \\
\text { GDP ratio } \\
\text { (\%) }\end{array}$ \\
\hline Armenia & 2,159 & 1,380 & 64 & 19.8 \\
Azerbaijan & 1,898 & 1,107 & 58 & 2.5 \\
Belarus & 1,258 & 576 & 46 & 1.7 \\
Estonia & 476 & 137 & 29 & 1.8 \\
Georgia & 2,065 & 1,233 & 60 & 12.5 \\
Kazakhstan & 209 & 133 & 64 & 0.1 \\
Kyrgyzstan & 2,246 & 1,735 & 77 & 30.3 \\
Latvia & 790 & 193 & 24 & 2.5 \\
Lithuania & 2,399 & 269 & 11 & 5.0 \\
Moldova & 1,981 & 656 & 33 & 24.9 \\
Tajikistan & 3,835 & 2,952 & 77 & 41.4 \\
Turkmenistan & 30 & 30 & 100 & 0.1 \\
Ukraine & 7,587 & 3,936 & 52 & 5.8 \\
Uzbekistan & 5,588 & 5,588 & 100 & 9.0 \\
\hline
\end{tabular}

Source: Calculations of the author based on data for total remittances and bilateral remittances from Russia (World Bank 2014)

Despite more than twenty years of independent development, interdependencies between the Russian and former Soviet economies are still strong. Figure 1 below illustrates that remittances are sensitive to changes in economic conditions in Russia. Whereas the global financial crisis hit the world economy in general, the slowdown in Russian economic growth had a particularly severe impact on the economies of the former Soviet Union countries. As a result, remittances and economic growth declined significantly, albeit

\footnotetext{
${ }^{4}$ It should be noted that the data on bilateral remittances from the World Bank used in constructing Tables 1 and 2 is not without ambiguities. For instance, according to World Bank estimations, Uzbekistan receives remittances only from Russia, whereas anecdotal evidence (as well as a number of surveys) indicates that the migrant stock of both legal and illegal Uzbek labourers in South Korea, Turkey, the USA, and especially Kazakhstan is sizeable too. For example, Makhmutova et al. (2008), using a survey financed by the Asian Development Bank, estimated that 2004 remittances from Kazakhstan to Uzbekistan were US\$500 million.
} 
temporarily, in the former Soviet Union countries, but bounced back after the Russian economy started to grow again.

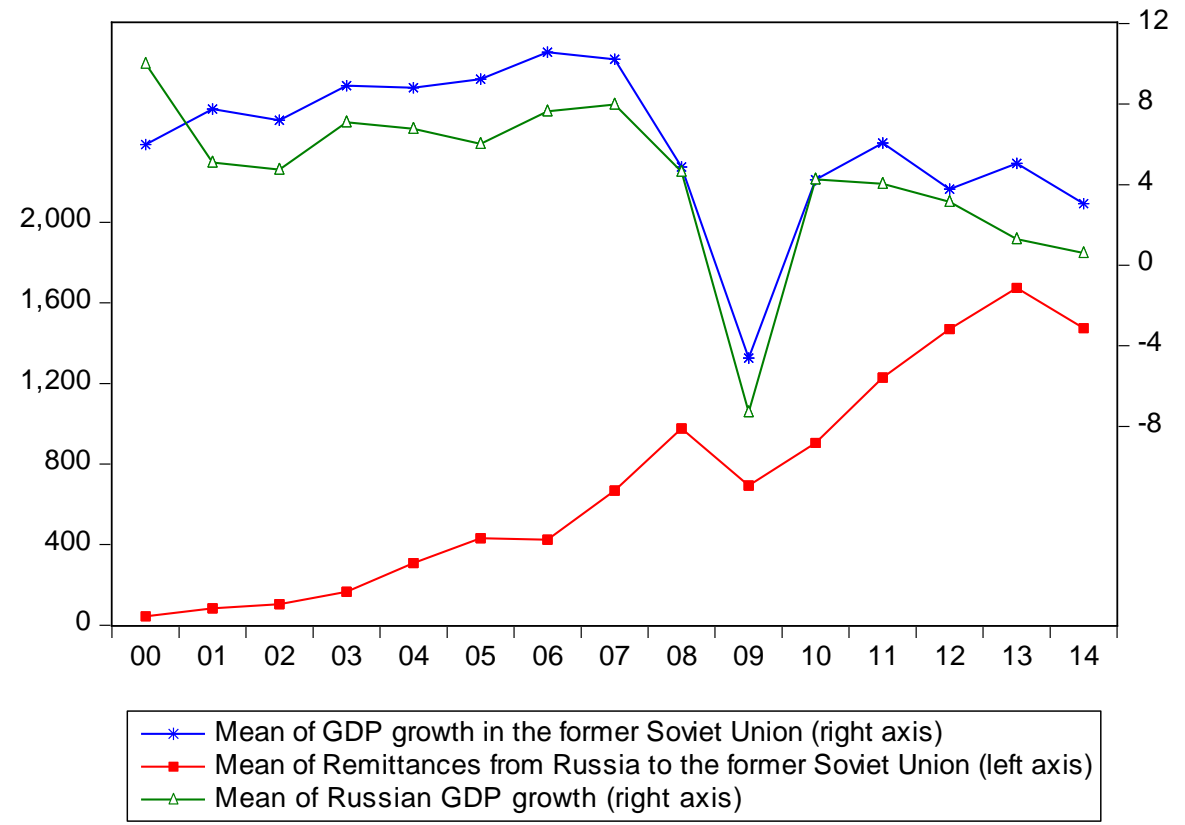

Figure 1. Remittances from Russia, GDP growth in Russia, and GDP growth in the former Soviet Union 2000-2014 (GDP growth in percentages and remittances in US\$ million).

\section{Data Description and Methodology}

\subsection{Data sources}

To determine the drivers of remittances in the former Soviet Union, the paper applies panel data analysis techniques and regresses remittances on a range of macroeconomic and demographic variables. The panel is unbalanced and covers a set of $11-12^{5}$ countries of the former Soviet Union over an 11-15 year period from 2000 to 2014.

Arguably, cross-country studies that estimate average coefficients may potentially produce erroneous results because this methodology may obscure diverse remittance flow patterns received by individual countries in a sample (Sayan 2006). Since the sample for this research includes countries with a common past, culture, mentality and, in some cases, a

\footnotetext{
${ }^{5}$ In all estimations, except for one of the IV regressions, the sample consists of 11 countries.
} 
similar trajectory of development, this heterogeneity problem is largely mitigated. By taking first differences between variables, it also becomes possible to eliminate many of the biases that arise from endogeneity and omitted variables, simultaneously addressing concerns about stationarity (Adams 2009).

Our data set differs from those of many existing cross-country studies in three important dimensions. First, previous research has relied on International Monetary Fund (IMF) data on remittances that has some errors and inconsistencies (Kakhkharov and Akimov 2015). The remittances series used in this paper use data from the Central Bank of Russia, collected from MTOs in Russia, on bilateral remittances for each of the countries of the Commonwealth of Independent States (CIS) and believed to be more reliable. The Central Bank of Russia publishes two sets of data on remittances: the total remittances of individuals from Russia to each of the CIS countries, and remittances implemented through MTOs. The difference between these two series is insubstantial. However, since labour migration from the CIS countries to Russia is predominantly seasonal and illegal, most migrants use MTOs because of their lower documentation requirements and relative accessibility. In addition, the data on total remittances from individuals is more likely to capture transactions which should not be classified as remittances. These may include gifts, money transfers made by tourists, and/or trade-related transactions. Therefore, in this study we use the statistics for remittances via $\mathrm{MTOs}^{6}$.

The second distinctive feature of the dataset is that the data contains good-quality observations for the major explanatory variable, which is the cost of remitting US\$200 from the Russian Federation for the period 2003-2013, collected by the Central Bank of Russia as

\footnotetext{
${ }^{6}$ The Central Bank of Russia data on annual remittances from Russia via MTOs covers the period from 2006 to 2014. For the period from 2000 to 2005, the study uses the bilateral remittance data estimated by Shelburne and Palacin (2007). This data series is not available for Estonia, for which the pro rata share of remittances from Russia is calculated according to IMF data on remittances to Estonia, and the World Bank estimate of the share of remittances from Russia.
} 
a result of regular surveys of MTOs operating in Russia. A quick overview of the relationship between these transfer fees and remittances from Russia reveals an interesting pattern: thus Figure 2 illustrates the inverse relationship between remittances from Russia to the former Soviet Union countries and remittance transfer fees.

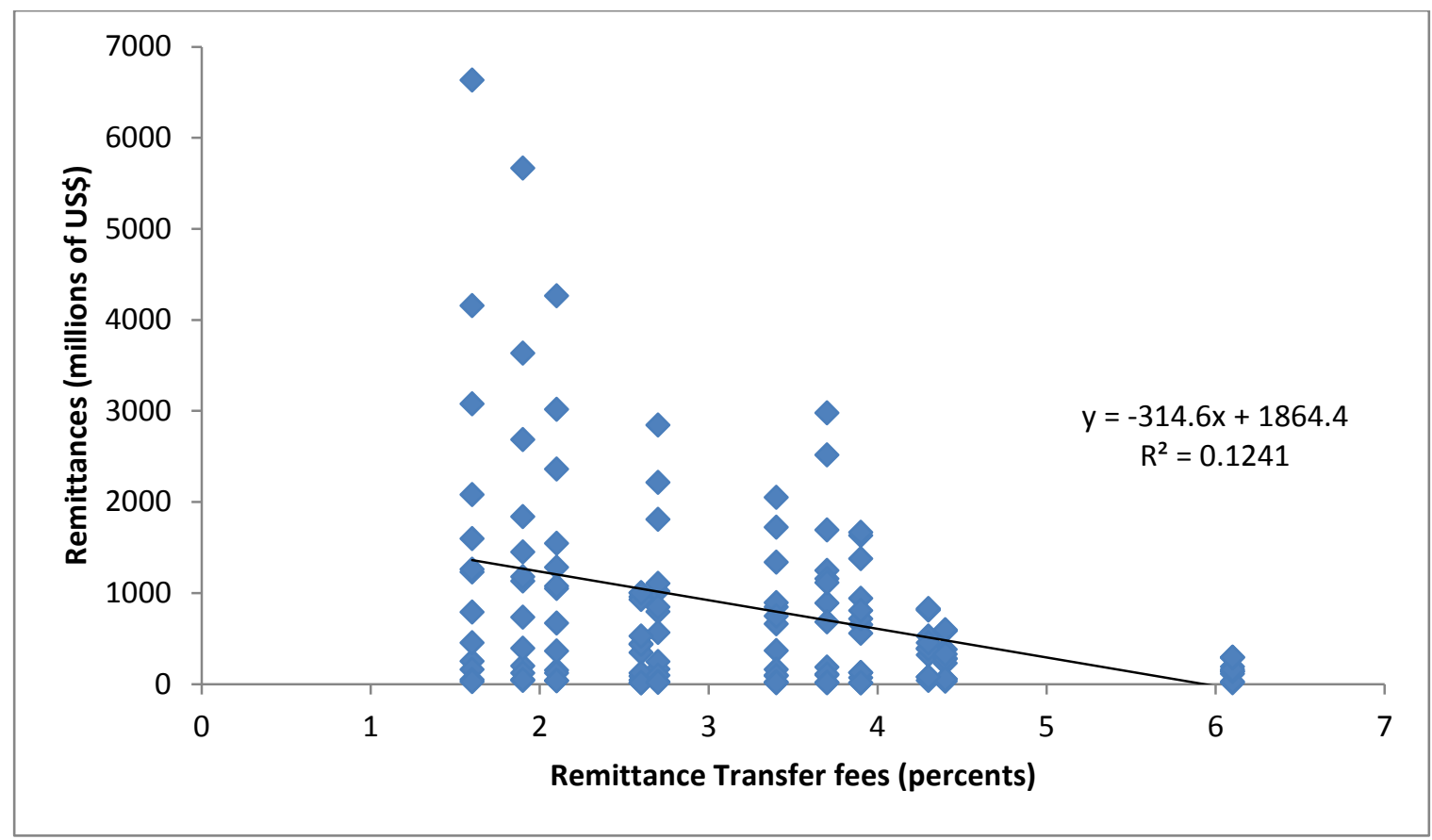

Figure 2. Remittances from Russia to the Former Soviet Union and Remittance Transfer Fees.

Thirdly, another explanatory variable - the number of migrants from each country of the former Soviet Union - is also collected from a single source: the Federal Migration Service (FMS) of Russia. These data were gathered from arrival cards processed by the territorial bodies of the FMS of Russia when migrants register at an address and explicitly indicate that they have arrived in Russia to work. Because migration to Russia has been highly seasonal, until 2011 this system covered only migrants moving to Russia for nine months or less. As of 2011, the system takes into account those who register for a period of longer than nine months. It should be noted that the data series for this variable is not faultless due to the difficulties in measuring illegal migration and due to frequent changes in the regulations governing labour migration in Russia. Overall, however, the series represents 
a reasonably good proxy for capturing fluctuations in the migrant flow and is expected to show a positive relationship with the volume of remittances. Finally, the study also uses data on the number of MTO service points implementing cross-border transfers from Russia in its instrumental variable (IV) estimations. This data was harvested from two reports of the Central Bank of Russia (2009, 2012).

The literature on the determinants of remittances discussed earlier also finds that business cycles, income levels, interest rates and the business environment are important factors in remittance flows. What matters for remittance decisions are the differences in these factors between the host and home countries. Therefore, in all estimations of remittance flows, the differences in GDP growth, GDP per capita and real interest rates between Russia and the other countries of the former Soviet Union are used as proxies for differences in business cycle, income level and business environment. All of these data series have been sourced from the World Bank's World Development Indicators.

A number of studies cited in the literature review indicate that the foreign exchange rates of the host and home countries, the development level of their financial sectors, and the macroeconomic instability of the home country are relevant to remittances. The recent economic recession in Russia, accompanied by the dramatic depreciation of the Russian rouble, decimated migrants' real earnings. For this reason, nominal US dollar exchange rates for the Russian rouble and the former Soviet republics' currencies are included in the estimations as explanatory variables. Financial sector development is expressed in terms of the ratio of credit to GDP and comes from the IMF's International Financial Statistics (IFS). Since inflation is perceived as a sign of macroeconomic instability, a GDP deflator from the World Development Indicators is also included in estimations as a proxy for the rate of inflation. 
A range of standard demographic and qualitative variables are used as control variables. This includes age dependency (used by Adams (2009) and Buch and Kuckulenz (2010)), multiple exchange rate regimes (used by Aydas et al. (2005) and El-Sakka and McNabb (1999)), economic crises, and the ease of crossing borders (used by Lueth and RuizArranz (2008)). An economic crisis in the host country, Russia, may stop labour migrants from coming to the host country and decrease the amount of remittances. While the model contains a few variables capturing changes in economic performance, an additional dummy in the model identifying the Russian economic crisis is warranted to account for the fact that economic crisis is a force majeure circumstance affecting migration and remittances much more profoundly and deeply compared to relatively minor fluctuations in economic performance. Therefore, this variable represents a dummy equal to 1 for the periods when Russia's economic growth was either negative or close to zero. Finally, the existence of common borders may facilitate informal remittances and depress formal remittances (Lueth and Ruiz-Arranz 2008). This is because having common borders and a visa trade regime makes it easy to travel to Russia and back, carrying the income earned in Russia in the pockets of migrants. However, having a common border may not necessarily make crossing the border with Russia easy because not all of the former Soviet Union enjoys a visa free regime with Russia. Estonian, Latvian, and Lithuanian citizens need a preapproved visa to visit Russia. Russia introduced a tougher a visa regime with Georgia in 2008, after the South Ossetia conflict. For other CIS countries, procedures for obtaining a work permit in Russia are much simpler compared to the non-CIS countries. Since Estonia, Latvia, and Lithuania have never been members of the CIS and Georgia exited the CIS in 2009, the citizens of these countries are subject to different treatment in Russia when applying for a work permit. Thus, despite having physical borders with Russia, some countries of the former Soviet Union that have a visa regime in place with Russia - Estonia, Latvia, Lithuania and Georgia (since 2008) 
- are assigned a category of not sharing a border, together with Armenia, Moldova, Uzbekistan, Kyrgyzstan and Tajikistan: the countries which do not share a physical border with Russia. Finally, since remittances have experienced strong growth in the former Soviet Union and there could be some other factors not captured by our model that might have accounted for this, a time trend variable is incorporated into all estimations.

The full description of the variables used in this study is provided in the Appendix.

\subsection{Empirical framework}

The analysis in this section involves the application of three different econometric techniques. Initially, the determinants of remittances were estimated using ordinary least squares (OLS) to set the general direction of the investigation. Then a panel data fixed effects model is used to account for unobserved time-invariant heterogeneity ${ }^{7}$. Moreover, to address potential problems with autocorrelation, all estimations are in differences. Finally, to tackle the issue of endogeneity in a systematic way, instrumental variables were applied. In all the estimations, standard errors are robust with regard to autocorrelation and heteroscedasticity. The basic relationship is

$$
\Delta \operatorname{Rem}_{i t}=\beta_{0}+\beta_{1} \Delta \operatorname{Cost}_{i t-1}+\beta_{2} \Delta M_{i t-1}+\beta_{3} \Delta y_{i t-1}+\lambda_{4} \Delta X_{i t-1}+\varepsilon_{i t}
$$

where Rem is the annual amount (in US dollars) of remittances from Russia, measured for different estimations in volume, or remittances per capita, or the ratio of remittances to GDP received by country $i$ in period $t$. Cost denotes the remittance transfer fees associated with sending remittances from Russia to country $i$ in period $t ; M$ is the flow of migrants to Russia from country $i$ in period $t ; y$ is the GDP growth differential between Russia and country $i$ in period $t ; X$ is a vector of other explanatory variables, which cover demographic, economic and financial/political factors, for country $i$ at time $t$; and $\varepsilon$ is an error term.

\footnotetext{
${ }^{7}$ A Hausman test confirmed the preference for fixed-effects models in these estimations.
} 
For fixed effects estimations, the following basic model is used:

$$
\Delta \operatorname{Rem}_{i t}=\alpha_{i}+\beta_{1} \Delta \operatorname{Cost}_{i t-1}+\beta_{2} \Delta M_{i t-1}+\beta_{3} \Delta y_{i t-1}+\lambda_{4} \Delta X_{i t-1}+\varepsilon_{i t}
$$

where $\alpha_{i}$ denotes the country-specific fixed effects and the other symbols have the same meanings as in Equation 1.

To overcome a problem of endogeneity, as a second step, instrumental variable estimations are applied. Five instrumental variables are carefully selected to avoid the potential problem of reverse causality. The overidentification test developed by Hansen (1982) is used in IV estimations to check the validity of instruments. The Hansen test is aimed at testing the null hypothesis that the instrument is uncorrelated with the error term and is correctly excluded from the regression equation.

\section{Results and Discussion}

\subsection{Determinants of remittances: pooled OLS and fixed effects model}

The results of estimation of the determinants of remittances are presented in Table 4 . These include output for both pooled OLS and fixed effects models for three remittance variables: (a) remittances to GDP ratio; (b) volume of remittances and (c) remittances per capita. Three types of remittance-related variables are used as dependent variables in order to confirm that the impact of the independent variables holds for various modifications of a dependent variable.

Table 4. Determinants of Remittances: Pooled OLS and Fixed Effects Panel Regression Results

\begin{tabular}{|c|c|c|c|c|c|c|}
\hline $\begin{array}{l}\text { Explanatory } \\
\text { variables }\end{array}$ & $\begin{array}{c}\text { Dependent } \\
\text { variable }\end{array}$ & $\begin{array}{c}\text { Dependent } \\
\text { variable }\end{array}$ & $\begin{array}{c}\text { Dependent } \\
\text { variable }\end{array}$ & $\begin{array}{c}\text { Dependent } \\
\text { variable }\end{array}$ & $\begin{array}{c}\text { Dependent } \\
\text { variable }\end{array}$ & $\begin{array}{c}\text { Dependent } \\
\text { variable }\end{array}$ \\
\hline & $\begin{array}{c}\text { Remittances } \\
\text { to GDP }\end{array}$ & $\begin{array}{l}\text { Remittances } \\
\text { volume }\end{array}$ & $\begin{array}{l}\text { Remittances } \\
\text { per capita }\end{array}$ & $\begin{array}{c}\text { Remittances } \\
\text { to GDP }\end{array}$ & $\begin{array}{c}\text { Remittances } \\
\text { volume }\end{array}$ & $\begin{array}{c}\text { Remittances } \\
\text { per capita }\end{array}$ \\
\hline & \multicolumn{3}{|c|}{ Pooled OLS } & \multicolumn{3}{|c|}{ Fixed effects } \\
\hline $\begin{array}{l}\text { Remittance } \\
\text { transfer fees }\end{array}$ & $\begin{array}{l}-0.73^{* *} \\
(-2.78)\end{array}$ & $\begin{array}{c}-39.70 * * \\
(-2.48)\end{array}$ & $\begin{array}{l}-5.98 * * \\
(-2.08)\end{array}$ & $\begin{array}{l}-0.75^{* *} \\
(-2.61)\end{array}$ & $\begin{array}{c}-35.58^{* *} \\
(-2.18)\end{array}$ & $\begin{array}{l}-5.51 * * \\
(-2.52)\end{array}$ \\
\hline
\end{tabular}




\begin{tabular}{|c|c|c|c|c|c|c|}
\hline $\begin{array}{l}\text { Explanatory } \\
\text { variables }\end{array}$ & $\begin{array}{c}\text { Dependent } \\
\text { variable }\end{array}$ & $\begin{array}{c}\text { Dependent } \\
\text { variable }\end{array}$ & $\begin{array}{c}\text { Dependent } \\
\text { variable }\end{array}$ & $\begin{array}{c}\text { Dependent } \\
\text { variable }\end{array}$ & $\begin{array}{c}\text { Dependent } \\
\text { variable }\end{array}$ & $\begin{array}{c}\text { Dependent } \\
\text { variable }\end{array}$ \\
\hline & $\begin{array}{c}\text { Remittances } \\
\text { to GDP }\end{array}$ & $\begin{array}{l}\text { Remittances } \\
\text { volume }\end{array}$ & $\begin{array}{l}\text { Remittances } \\
\text { per capita }\end{array}$ & $\begin{array}{c}\text { Remittances } \\
\text { to GDP }\end{array}$ & $\begin{array}{l}\text { Remittances } \\
\text { volume }\end{array}$ & $\begin{array}{l}\text { Remittances } \\
\text { per capita }\end{array}$ \\
\hline & \multicolumn{3}{|c|}{ Pooled OLS } & \multicolumn{3}{|c|}{ Fixed effects } \\
\hline Migrants & $\begin{array}{c}0.001 \\
(0.002)\end{array}$ & $\begin{array}{l}0.03 * * \\
(2.02)\end{array}$ & $\begin{array}{l}0.001 \\
(0.50)\end{array}$ & $\begin{array}{l}-0.001 \\
(-0.46)\end{array}$ & $\begin{array}{c}0.01 \\
(0.32)\end{array}$ & $\begin{array}{l}-0.001 \\
(-0.35)\end{array}$ \\
\hline $\begin{array}{l}\text { GDP growth } \\
\text { differential }\end{array}$ & $\begin{array}{l}0.028 \\
(0.8)\end{array}$ & $\begin{array}{c}0.03 \\
(0.01)\end{array}$ & $\begin{array}{l}-0.08 \\
(-0.21)\end{array}$ & $\begin{array}{c}0.03 \\
(1.03)\end{array}$ & $\begin{array}{c}1.33 \\
(0.65)\end{array}$ & $\begin{array}{c}0.12 \\
(0.31)\end{array}$ \\
\hline $\begin{array}{l}\text { Income } \\
\text { differential }\end{array}$ & $\begin{array}{l}-0.001 \\
(-0.44)\end{array}$ & $\begin{array}{c}0.02 \\
(0.54)\end{array}$ & $\begin{array}{l}-0.001 \\
(-0.17)\end{array}$ & $\begin{array}{l}-0.001 \\
(-0.84)\end{array}$ & $\begin{array}{c}0.01 \\
(0.18)\end{array}$ & $\begin{array}{l}-0.001 \\
(-0.37)\end{array}$ \\
\hline $\begin{array}{l}\text { Interest rate } \\
\text { differential }\end{array}$ & $\begin{array}{l}-0.03 \\
(-1.63)\end{array}$ & $\begin{array}{l}-1.94 \\
(-1.24)\end{array}$ & $\begin{array}{l}-0.42^{* *} \\
(-2.01)\end{array}$ & $\begin{array}{c}-0.03 \\
(-1.47) \\
\end{array}$ & $\begin{array}{c}-0.37 \\
(-0.47)\end{array}$ & $\begin{array}{c}-0.29 \\
(-1.15) \\
\end{array}$ \\
\hline $\begin{array}{l}\text { Foreign } \\
\text { exchange rate } \\
\text { in home } \\
\text { country }\end{array}$ & $\begin{array}{l}0.001 \\
(0.38)\end{array}$ & $\begin{array}{l}-0.03^{* *} \\
(-2.77)\end{array}$ & $\begin{array}{l}-0.001 \\
(-0.88)\end{array}$ & $\begin{array}{l}-0.001 \\
(-0.92)\end{array}$ & $\begin{array}{c}-0.01 \\
(-0.31)\end{array}$ & $\begin{array}{l}-0.001 \\
(-0.51)\end{array}$ \\
\hline $\begin{array}{l}\text { Foreign } \\
\text { exchange rate } \\
\text { in host country }\end{array}$ & $\begin{array}{l}-0.29 * * \\
(-2.07)\end{array}$ & $\begin{array}{c}-41.09 * * * \\
(-3.43)\end{array}$ & $\begin{array}{c}-6.06^{* * * *} \\
(-4.4)\end{array}$ & $\begin{array}{c}-0.24 \\
(-1.32)\end{array}$ & $\begin{array}{c}-56.56^{* * *} \\
(-6.6)\end{array}$ & $\begin{array}{c}-8.39 * * * \\
(-6.42)\end{array}$ \\
\hline $\begin{array}{l}\text { Unemployment } \\
\text { in home } \\
\text { country }\end{array}$ & $\begin{array}{c}0.03 \\
(0.75)\end{array}$ & $\begin{array}{c}6.55 \\
(0.55)\end{array}$ & $\begin{array}{c}4.21 \\
(1.41)\end{array}$ & $\begin{array}{c}0.04 \\
(0.93)\end{array}$ & $\begin{array}{l}12.55 \\
(1.28)\end{array}$ & $\begin{array}{c}5.48 \\
(1.59)\end{array}$ \\
\hline $\begin{array}{l}\text { Age } \\
\text { dependency }\end{array}$ & $\begin{array}{l}-0.89 \\
(-1.4)\end{array}$ & $\begin{array}{l}-73.32 \\
(-1.55)\end{array}$ & $\begin{array}{c}-17.21^{* *} \\
(-2.03)\end{array}$ & $\begin{array}{l}-1.50 \\
(-1.23)\end{array}$ & $\begin{array}{l}85.19^{*} \\
(1.81)\end{array}$ & $\begin{array}{c}4.92 \\
(0.49) \\
\end{array}$ \\
\hline Credit to GDP & $\begin{array}{l}-0.0002 \\
(-0.008)\end{array}$ & $\begin{array}{c}-2.14 \\
(-1.51)\end{array}$ & $\begin{array}{c}0.24 \\
(0.46)\end{array}$ & $\begin{array}{c}0.01 \\
(0.47) \\
\end{array}$ & $\begin{array}{l}-3.43^{* *} \\
(-2.54)\end{array}$ & $\begin{array}{c}0.02 \\
(0.04) \\
\end{array}$ \\
\hline Inflation & $\begin{array}{l}0.005 \\
(0.24)\end{array}$ & $\begin{array}{c}0.14 \\
(0.11)\end{array}$ & $\begin{array}{c}0.21 \\
(0.98)\end{array}$ & $\begin{array}{c}0.01 \\
(0.52)\end{array}$ & $\begin{array}{c}-0.66 \\
(-0.61)\end{array}$ & $\begin{array}{c}0.15 \\
(0.46)\end{array}$ \\
\hline $\begin{array}{l}\text { Dual exchange } \\
\text { rates }\end{array}$ & $\begin{array}{c}0.44 \\
(1.03)\end{array}$ & $\begin{array}{l}75.8 \\
(1.47)\end{array}$ & $\begin{array}{c}2.76 \\
(0.53)\end{array}$ & $\begin{array}{c}-0.15 \\
(-0.22)\end{array}$ & $\begin{array}{l}90.22 \\
(1.41)\end{array}$ & $\begin{array}{l}14.28 \\
(1.61)\end{array}$ \\
\hline $\begin{array}{l}\text { Economic } \\
\text { crises }\end{array}$ & $\begin{array}{l}-2.74 \\
(-1.61)\end{array}$ & $\begin{array}{l}-163.9 \\
(-1.10)\end{array}$ & $\begin{array}{l}-64.16 \\
(-1.62)\end{array}$ & $\begin{array}{l}-3.66 \\
(-1.7)^{*}\end{array}$ & $\begin{array}{l}-150.61 \\
(-1.04)\end{array}$ & $\begin{array}{l}-59.47 \\
(-1.29)\end{array}$ \\
\hline Border & $\begin{array}{c}-0.99 \\
(-2.19)\end{array}$ & $\begin{array}{l}15.89 \\
(0.68)\end{array}$ & $\begin{array}{c}-19.14^{* *} \\
(-2.56)\end{array}$ & $\begin{array}{c}-0.33 \\
(-0.41)\end{array}$ & $\begin{array}{c}77 \\
(1.15)\end{array}$ & $\begin{array}{l}14.79 \\
(0.78)\end{array}$ \\
\hline Trend & $\begin{array}{l}0.29 * * \\
(2.15)\end{array}$ & $\begin{array}{c}40.43^{* *} \\
(2.63)\end{array}$ & $\begin{array}{c}6.76^{* * *} \\
(3.1)\end{array}$ & $\begin{array}{c}0.44^{* * *} \\
(4.68)\end{array}$ & $\begin{array}{c}29.97^{* *} \\
(3.05)\end{array}$ & $\begin{array}{l}5.36 * * \\
(2.90)\end{array}$ \\
\hline Constant & $\begin{array}{l}5.89 \\
(1.6)\end{array}$ & $\begin{array}{c}872.16^{* * *} \\
(2.7)\end{array}$ & $\begin{array}{c}134.13^{* * * *} \\
(3.82)\end{array}$ & $\begin{array}{c}2.9 \\
(0.5)\end{array}$ & $\begin{array}{c}1517.4^{* * *} \\
(6.94)\end{array}$ & $\begin{array}{c}218.99 * * * \\
(4.94)\end{array}$ \\
\hline Observations & 91 & 91 & 91 & 91 & 91 & 91 \\
\hline $\begin{array}{l}\text { Number of } \\
\text { countries }\end{array}$ & 11 & 11 & 11 & 11 & 11 & 11 \\
\hline R-squared & 0.31 & 0.52 & 0.56 & 0.35 & 0.65 & 0.64 \\
\hline
\end{tabular}

Country fixed effects

\begin{tabular}{lcccc}
\hline Armenia & 2.47 & 1603.10 & 259.77 \\
\hline Azerbaijan & 1.02 & 1525.28 & 206.05 \\
\hline Belarus & 3.57 & 1372.68 & 198.51 \\
\hline
\end{tabular}




\begin{tabular}{lcccccc}
\hline $\begin{array}{l}\text { Explanatory } \\
\text { variables }\end{array}$ & $\begin{array}{c}\text { Dependent } \\
\text { variable }\end{array}$ & $\begin{array}{c}\text { Dependent } \\
\text { variable }\end{array}$ & $\begin{array}{c}\text { Dependent } \\
\text { variable }\end{array}$ & $\begin{array}{c}\text { Dependent } \\
\text { variable }\end{array}$ & $\begin{array}{c}\text { Dependent } \\
\text { variable }\end{array}$ & $\begin{array}{c}\text { Dependent } \\
\text { variable }\end{array}$ \\
\hline & $\begin{array}{c}\text { Remittances } \\
\text { to GDP }\end{array}$ & $\begin{array}{c}\text { Remittances } \\
\text { volume }\end{array}$ & $\begin{array}{c}\text { Remittances } \\
\text { per capita }\end{array}$ & $\begin{array}{c}\text { Remittances } \\
\text { to GDP }\end{array}$ & $\begin{array}{c}\text { Remittances } \\
\text { volume }\end{array}$ & $\begin{array}{c}\text { Remittances } \\
\text { per capita }\end{array}$ \\
\hline Georgia & Pooled OLS & & \multicolumn{3}{c}{ Fixed effects } & \\
\hline Kyrgyzstan & & 2.81 & 1385.86 & 202.57 \\
\hline Moldova & & 3.59 & 1618.73 & 239.26 \\
\hline Tajikistan & & 2.34 & 1543.60 & 237.11 \\
\hline Ukraine & & 3.29 & 1881.58 & 258.69 \\
\hline Estonia & & 3.27 & 1549.65 & 187.32 \\
\hline Latvia & & 3.50 & 1347.66 & 204.35 \\
\hline Lithuania & & 3.38 & 1321.63 & 195.52 \\
\hline
\end{tabular}

Note: $* * *, * *$, and $*$ denote significance at, respectively, the 1,5 , and 10 per cent levels. Absolute values of robust $t$-statistics are in parentheses.

Interpretation of the coefficients, derived from both the pooled OLS and fixed effects estimations, results in a reasonably consistent story. Remittance transfer fees and foreign exchange rate in Russia have the most persistent, strongest and most statistically significant impacts on remittances, no matter which measure of remittances is used. The number of migrants was expected to have a positive relationship with the volume of remittances. However, this variable is significant only in pooled estimations. In contrast to some other studies in the area (Freund and Spatafora 2008; Singh et al. 2010), in fixed effects models this positive relationship is not statistically significant. As discussed above, frequent changes in regulations on the classification of migrants may have been a reason behind this. Intuitively, it is clear why the foreign exchange rate in Russia proved to be an important driver of remittances: with a fall of the rouble, remittances fall too. The anecdotal evidence of this phenomenon taking place in Russia today is plentiful and it is notable that this effect is statistically significant in five out of the six regressions. Another indicator which was expected to have a positive sign is the trend variable. As noted above, over time, remittances from Russia to the former Soviet Union increased substantially and there could be factors other than those we were able to capture in the model. Therefore, it is not surprising that the 
trend variable has a positive sign and its effect is statistically significant in five out of the six regressions.

\subsection{Determinants of remittances: instrumental variable estimations}

Despite the robust results of OLS and fixed effects estimations pointing at remittance transfer fees as the main determinant of remittances in the former Soviet Union, it is still possible that remittance transfer fees are endogenous to remittances. Although fixed effects estimations in first differences and lagging independent variables decreased the biases, reverse causality may be taking place: remittances may be affecting the remittance transfer fees while, in addition, remittance transfer fees may be affecting remittances. One potential solution to this problem is to use instrumental variable estimations. Proper external instrumental variables that are correlated with the endogenous explanatory variable, but uncorrelated with the outcome variable applied in a panel model, may eliminate many biases that arise from endogeneity concerns.

The main challenge is finding appropriate instruments to use as variables. In this study, five potentially appropriate instruments were identified. One of these instruments is the number of MTO service points in Russia. Recently, many banks and other financial institutions have entered the money transfer market, decreasing the remittance transfer fees being charged. The number of MTOs in Russia increased from just a few in the 1990s to more than 20 in the 2000s, facilitated by liberal policies toward MTOs on the part of Russian regulators, as well as those in the majority of the former Soviet Union countries. The increased competition among service providers undoubtedly contributed to reductions in remittance transfer fees. The number of MTO service points reflects the level of competition among MTOs in the remittance transfer market and is, therefore, a suitable instrument for the estimations. It is expected that the number of MTO service points will be negatively 
correlated with remittance transfer fees. At first glance, it seems that this variable is correlated with the error term; as remittances increase, the number of MTOs may also increase. However, this relationship does not always hold. Data from research by Orozco (2006) on the Latin American remittance market shows that the number of competitors in the remittance market may remain relatively stable even if remittances continue to increase.

The other four potential instruments reflect characteristics of the financial systems in the remittance-receiving countries of the former Soviet Union, which are deemed to influence the transfer fees. These are the ratio of current deposits to GDP, the level of bank concentration, the number of bank branches per 100,000 adults, and the number of ATMs per 100,000 adults. There are two potential channels by which these variables relate to MTO transfer fees. Firstly, more efficient and competitive financial systems as a whole may reflect the state of development of MTO markets in these countries (negative relationships between remittance transfer fees and competition in financial sectors). Indeed, some of the banks in the former Soviet Union provide MTO services by acting as agents of MTOs or developing their own MTO network. Secondly, there might be a substitution effect between the traditional banking sector and MTOs, where more efficient and competitive banking services pull customers from MTOs.

The ratio of current deposits to GDP is a proxy for the level of trust in the banking sector, which facilitates the transfer of remittances through official channels, thereby affecting remittance transfer fees. Thus, a greater ratio of transferrable deposits should have a negative impact on such costs. A large number of bank branches creates convenience for the families of labour migrants - the principal beneficiaries of remittances - thereby increasing the demand for transfers through MTOs. This may result in higher fees. On the other hand, a larger number of bank branches may create a more competitive environment and lower fees. Bank concentration is an important indicator of the level of competition in the banking sector 
and the literature on remittances finds it to be a factor relevant to transfer costs (Freund and Spatafora 2008). A high level of bank concentration may result in the stifling of competition and lead to higher transfer costs. The number of ATMs per 100,000 of the adult population is another factor, similar to the number of bank branches, and reflects the penetration rate of banking services, and is hence relevant to remittance transfer fees, having equivocal net effects. 
Table 5. First-stage IV estimates for remittance transfer fees of remittances from Russia to the former Soviet Union countries

\begin{tabular}{lc}
\hline Instruments & \\
\hline The number of MTO service points in Russia & $-0.00^{* * *}(-4.77)$ \\
Bank branches per 100,000 adults & $0.04(0.58)$ \\
Bank concentration ratio & $0.01^{* * *}(3.72)$ \\
Ratio of transferable deposits to GDP & $-0.01(-0.29)$ \\
ATMs per 100,000 adults & $-0.02(-1.33)$ \\
\hline Exogenous variables & \\
\hline GDP growth differential & $0.02 * * *(3.26)$ \\
Income differential & $-0.00(-0.14)$ \\
Interest rate differential & $-0.01(-1.32)$ \\
Foreign exchange rate in home country & $0.00(1.18)$ \\
Foreign exchange rate in host country & $-0.47 * * *(-6.15)$ \\
Unemployment in home country & $-0.07(-1.02)$ \\
Age dependency & $-0.19(-0.32)$ \\
Credit to GDP & $0.00(0.33)$ \\
Migrants & $0.00(1.36)$ \\
Inflation & $-0.01^{* *}(-2.58)$ \\
Dual exchange rates & $-0.24(-0.76)$ \\
Economic crisis & $2.36^{* *}(2.78)$ \\
Border & $-0.22(-0.73)$ \\
Trend & $0.79 * * *(9.00)$ \\
Constant & $9.25^{* * *}(7.11)$ \\
Observations & 56 \\
Rumber of countries & 11 \\
and & 0.89 \\
\hline
\end{tabular}

Note: $* * *, * *$, and $*$ denote significance at, respectively, the 1,5 , and 10 per cent levels. Absolute values of robust $t$-statistics are in parentheses.

Table 5 presents the first-stage results for the instrumented variable (remittance transfer fees).

Two instrumental variables out of five are significant for the prediction of transfer costs. As expected, growth in the number of MTOs decreases the remittance transfer fees, and higher bank concentrations work in the opposite direction. In accordance with the preliminary expectations, the sign for the ratio of transferrable deposits to GDP is negative, although this effect is not statistically significant. The other two variables - the number of bank branches 
and the number of ATMs per 100,000 adults - are also statistically insignificant, albeit having different signs. However, the ambiguity in these effects is not surprising either. Overall, these results suggest that the instruments are relevant. Therefore, these instruments are used in the second-stage estimations, and the second-stage IV results are presented in Table 6. 
Table 6. Determinants of remittances: IV estimates of the impact of transfer costs on remittances from Russia to the countries of the former Soviet Union

\begin{tabular}{|c|c|c|c|c|}
\hline $\begin{array}{l}\text { Instrumented endogenous } \\
\text { variable }\end{array}$ & \multicolumn{4}{|c|}{ Dependent variable: Remittances to $G D P^{8}$} \\
\hline Remittance transfer fees & $\begin{array}{l}-0.47^{* *} \\
(-2.69) \\
\end{array}$ & $\begin{array}{l}-0.44^{* *} \\
(-2.61)\end{array}$ & $\begin{array}{l}-0.38 * * \\
(-2.45) \\
\end{array}$ & $\begin{array}{l}-0.35 * * \\
(-2.75)\end{array}$ \\
\hline \multicolumn{5}{|l|}{ Exogenous regressors } \\
\hline GDP growth differential & $\begin{array}{l}0.07 \\
(1.6)\end{array}$ & $\begin{array}{c}0.06 \\
(1.51)\end{array}$ & $\begin{array}{c}0.05 \\
(1.28) \\
\end{array}$ & $\begin{array}{c}0.05 \\
(1.36)\end{array}$ \\
\hline Income differential & $\begin{array}{l}-0.00 * * \\
(-2.84)\end{array}$ & $\begin{array}{l}-0.00 * * \\
(-2.64)\end{array}$ & $\begin{array}{l}-0.00^{*} \\
(-1.88)\end{array}$ & $\begin{array}{c}-0.00 * * \\
(-2.71)\end{array}$ \\
\hline Interest rate differential & $\begin{array}{l}0.04 * * \\
(-2.14)\end{array}$ & $\begin{array}{l}-0.03^{*} \\
(-1.94)\end{array}$ & & $\begin{array}{l}-0.03^{*} \\
(-1.92)\end{array}$ \\
\hline $\begin{array}{l}\text { Foreign exchange rate in home } \\
\text { country }\end{array}$ & $\begin{array}{l}-0.00 \\
(-1.14)\end{array}$ & $\begin{array}{l}-0.00 \\
(-0.81)\end{array}$ & $\begin{array}{c}-0.00 \\
(-0.43)\end{array}$ & $\begin{array}{l}-0.00 \\
(-0.77)\end{array}$ \\
\hline $\begin{array}{l}\text { Foreign exchange rate in host } \\
\text { country }\end{array}$ & $\begin{array}{l}0.61^{* *} \\
(2.41)\end{array}$ & $\begin{array}{l}0.61^{* *} \\
(2.48)\end{array}$ & $\begin{array}{l}0.52 * * \\
(2.31)\end{array}$ & $\begin{array}{l}0.42 * * \\
(2.22)\end{array}$ \\
\hline Unemployment in home country & $\begin{array}{l}0.07^{*} \\
(1.72)\end{array}$ & $\begin{array}{l}0.07^{*} \\
(1.71)\end{array}$ & $\begin{array}{c}0.05 \\
(1.12)\end{array}$ & $\begin{array}{l}0.06^{*} \\
(1.82)\end{array}$ \\
\hline Age dependency & $\begin{array}{l}-2.18 \\
(1.6)\end{array}$ & $\begin{array}{l}-1.79^{*} \\
(-1.78)\end{array}$ & $\begin{array}{l}-1.96 \\
(-1.55)\end{array}$ & \\
\hline Credit to GDP & $\begin{array}{l}0.02^{*} \\
(1.64)\end{array}$ & $\begin{array}{c}0.01 \\
(1.51)\end{array}$ & $\begin{array}{l}0.02 * \\
(1.8)\end{array}$ & $\begin{array}{c}0.01 \\
(0.73)\end{array}$ \\
\hline Migrants & $\begin{array}{c}-0.00^{* *} \\
(-2.62)\end{array}$ & $\begin{array}{l}-0.00^{* *} \\
(-2.71)\end{array}$ & $\begin{array}{l}-0.00^{* *} \\
(-2.64)\end{array}$ & $\begin{array}{c}-0.00^{* *} \\
(-2.1)\end{array}$ \\
\hline Inflation & $\begin{array}{l}0.03^{*} \\
(1.78)\end{array}$ & $\begin{array}{c}0.02 \\
(1.45)\end{array}$ & $\begin{array}{l}0.0008 \\
(0.07) \\
\end{array}$ & $\begin{array}{c}0.02 \\
(1.54)\end{array}$ \\
\hline Dual exchange rates & $\begin{array}{c}-0.75 \\
(-1.05)\end{array}$ & & $\begin{array}{l}-0.49 \\
(-0.8)\end{array}$ & $\begin{array}{c}0.2 \\
(0.36)\end{array}$ \\
\hline Economic crisis & $\begin{array}{l}-6.20^{* *} \\
(-2.81)\end{array}$ & $\begin{array}{c}-6.24 * * * \\
(2.91)\end{array}$ & $\begin{array}{l}-5.32 * * \\
(-1.99)\end{array}$ & $\begin{array}{c}-4.59 * * \\
(-2.78)\end{array}$ \\
\hline Border & $\begin{array}{c}-0.02 \\
(-0.02)\end{array}$ & & $\begin{array}{c}0.16 \\
(0.16)\end{array}$ & $\begin{array}{c}1.03 \\
(1.44)\end{array}$ \\
\hline Trend & $\begin{array}{c}0.25 \\
(1.41)\end{array}$ & $\begin{array}{c}0.14 \\
(1.14)\end{array}$ & $\begin{array}{l}0.27 \\
(1.5)\end{array}$ & $\begin{array}{l}-0.07 \\
(-0.59)\end{array}$ \\
\hline \multicolumn{5}{|l|}{ Statistics } \\
\hline Observations & 58 & 58 & 68 & 58 \\
\hline Number of countries & 11 & 11 & 12 & 11 \\
\hline R-squared & 0.42 & 0.41 & 0.38 & 0.41 \\
\hline $\begin{array}{l}\text { Kleibergen-Paap } \\
\text { (underidentification test) }\end{array}$ & 19.27 & 17.55 & 19.64 & 18.67 \\
\hline $\begin{array}{l}\text { Cragg-Donald Wald F statistic } \\
\text { (weak identification test) }\end{array}$ & 15.42 & 17.42 & 20.49 & 19.11 \\
\hline $\begin{array}{l}\text { Kleibergen-Paap rk Wald F } \\
\text { statistic (weak identification test) }\end{array}$ & 39.87 & 38.38 & 39.72 & 47.18 \\
\hline $\begin{array}{l}\text { Hansen J-statistic } \\
\text { (overidentification test) }\end{array}$ & 5.40 & 5.78 & 4.52 & 6.24 \\
\hline P-value Hansen test & 0.24 & 0.22 & 0.34 & 0.18 \\
\hline
\end{tabular}

\footnotetext{
${ }^{8}$ The focus in this study is on remittances to GDP ratio, rather than volume of remittances or remittances per capita, because data for population and immigration seems to be less reliable than GDP data. More detailed discussion of the problems in measuring this data can be found in Makaryan (2015).
} 
In the IV estimations, the coefficient for remittance transfer fees has dropped in comparison with the OLS and fixed effects regressions. This leads to the conclusion that the effect of remittance transfer fees in the baseline estimation might have been overestimated. However, this impact is still persistent, negative and statistically significant. Interestingly, the economic crisis and unemployment variables are significant in the IV estimations, the former with large negative coefficient. Both are in line with expectations.

Various tests confirm the validity of the identification strategy used for the IV estimations. The Cragg and Donald (1993) and Kleibergen and Paap (2006) tests for weak instruments are used to verify the identification of the model. The value of the Cragg-Donald test ranges from 15.42 to 20.49 and the Kleibergen-Paap test statistic fluctuates between 38.38 and 47.18, depending on the specification used. Both of these indicators exceed the rule-of-thumb score of 10 , indicating suitable correlations between the instruments and the remittance transfer fees. In all of our specifications, the Hansen overidentification test suggests that the instruments related to economic conditions and the financial sector used in the model are exogenous to remittance transfer fees. Therefore, their use in our model is warranted.

\section{Conclusion}

One of the attractive characteristics of remittances is the fact that these transfers are unilateral and do not require an explicit payback. However, another broadly accepted consensus - that remittances are a relatively stable source of foreign exchange flow - may not hold. The recent drastic cutback in remittances as a result of the Russian economic slowdown hurt those economies of the former Soviet Union that were dependent on the Russian remittances especially badly. This observation should warn against complacency among economic policymakers in the transition and less developed economies. As 
remittances might be rather volatile, policymakers should support remittances with sound macroeconomic policies and a favourable business environment in order to maximize the potential benefits of this inflow.

One way of increasing gains from remittances is to create incentives to channel remittances through the formal sector of the economy so that foreign exchange flows reach transparent and legitimate investment projects instead of letting informal sector activities use these funds. An important finding of this paper is that formal remittances are negatively associated with remittance transfer costs. This result, and other research in the field, such as that by Freund and Spatafora (2008), hints at the possibility that a statistically significant negative correlation between remittances and remittance transfer fees may lead to channelling of funds to the formal sector at the cost of shrinking informal sector inflows. Obviously, to achieve this goal, prudent, efficient regulation of the financial system and a favourable business environment must be in place (Akimov and Dollery 2008).

Several policy implications may be drawn from these findings. First of all, increasing the proportion of formal remittances is likely to improve the 'bankability' of the population. This could be the first step for beneficiaries of remittances in starting to use banking services in countries where the penetration of banking services is still low. This opportunity should be augmented by a correspondingly astute relationship management strategy aimed at retaining these beneficiaries once they are within the financial system. Second, a shift from the informal to the formal sector also allows more accurate measurement of remittances, which, in turn, permits a better estimation of funds available for investment in the economy. In addition, this makes any empirical inquiry into the effects of remittances more reliable. Third, despite the fact that lower remittance transfer fees may obviously result in a decrease in fee revenues per transfer, the overall revenues of the system may rise due to the increased volume of remittances flowing through formal channels. Last, but not least, the shift from 
informality to formality is a profound issue in the modern-day international security landscape. The ever-increasing threat of terrorism necessitates the close monitoring of international flows of funds, which is considerably easier to accomplish when funds flow through transparent, formal channels. 


\section{Appendix}

\begin{tabular}{|c|c|c|}
\hline Variable & Definition & Source \\
\hline $\begin{array}{l}\text { Remittance transfer } \\
\text { fees }\end{array}$ & $\begin{array}{l}\text { Average weighted cost for transfer of US } \$ 200 \text { from the } \\
\text { Russian Federation for the period } 2003-2013 \text {. }\end{array}$ & $\begin{array}{l}\text { Collected by the Central } \\
\text { Bank of Russia in regular } \\
\text { surveys of MTOs operating } \\
\text { in Russia }\end{array}$ \\
\hline $\begin{array}{l}\text { GDP growth } \\
\text { differential }\end{array}$ & $\begin{array}{l}\text { Difference in the GDP growth indicator between Russia } \\
\text { and the respective home countries of migrants. }\end{array}$ & $\begin{array}{l}\text { GDP data from World } \\
\text { Development Indicators } \\
\text { (WDI), World Bank }\end{array}$ \\
\hline Income differential & $\begin{array}{l}\text { Difference in GDP per capita between Russia and the } \\
\text { respective home countries of migrants. }\end{array}$ & $\begin{array}{l}\text { GDP per capita data from } \\
\text { WDI }\end{array}$ \\
\hline $\begin{array}{l}\text { Interest rate } \\
\text { differential }\end{array}$ & $\begin{array}{l}\text { Difference in real interest rates between Russia and the } \\
\text { respective home countries of migrants. Real interest rate is } \\
\text { the lending interest rate adjusted for inflation as measured } \\
\text { by the GDP deflator. The terms and conditions attached to } \\
\text { lending rates differ by country, however, limiting their } \\
\text { comparability. }\end{array}$ & $\begin{array}{l}\text { Real interest rate data is } \\
\text { from WDI }\end{array}$ \\
\hline $\begin{array}{l}\text { Foreign exchange } \\
\text { rate in home } \\
\text { country }\end{array}$ & $\begin{array}{l}\text { The official exchange rate refers to the exchange rate } \\
\text { determined by national authorities or to the rate determined } \\
\text { in the legally sanctioned exchange market. It is calculated } \\
\text { as an annual average based on monthly averages (local } \\
\text { currency units relative to the US dollar). }\end{array}$ & WDI \\
\hline $\begin{array}{l}\text { Foreign exchange } \\
\text { rate in host country }\end{array}$ & Idem & Idem \\
\hline $\begin{array}{l}\text { Unemployment in } \\
\text { home country total } \\
\text { (\% of total labour } \\
\text { force) (modelled } \\
\text { ILO estimate) }\end{array}$ & $\begin{array}{l}\text { Unemployment refers to the share of the labour force that } \\
\text { is without work but available for and seeking employment. }\end{array}$ & Idem \\
\hline
\end{tabular}

\begin{tabular}{lll}
\hline $\begin{array}{l}\text { Age dependency } \\
\text { (\% of working-age } \\
\text { population) }\end{array}$ & $\begin{array}{l}\text { The age dependency ratio is the ratio of dependents - } \\
\text { people younger than 15 or older than 64 - to the working- } \\
\text { age population - those aged 15-64. Data is shown as the } \\
\text { proportion of dependents per 100 of the working-age } \\
\text { population. }\end{array}$ & Idem \\
\hline Credit to GDP & $\begin{array}{l}\text { Deposit money banks' credit extended to the private sector } \\
\text { expressed as a percentage of GDP. }\end{array}$ & $\begin{array}{l}\text { International Financial } \\
\text { Statistics, IMF }\end{array}$ \\
\hline Migrants & $\begin{array}{l}\text { The number of citizens from the former Soviet Union who } \\
\text { came to Russia to work. }\end{array}$ & $\begin{array}{l}\text { Federal Migration Service } \\
\text { of the Russian Federation }\end{array}$ \\
\hline Inflation (\%) & GDP deflator (annual \%) & WDI \\
\hline Dual exchange & Dummy equals 1 indicates the presence of multiple & IMF Annual Report on \\
\hline
\end{tabular}




\begin{tabular}{|c|c|c|}
\hline Variable & Definition & Source \\
\hline rates & exchange rates. & $\begin{array}{l}\text { Exchange Arrangements } \\
\text { and Exchange Restrictions }\end{array}$ \\
\hline Economic crisis & $\begin{array}{l}\text { Dummy equals } 1 \text { for years when economic growth in } \\
\text { Russia was negative (2009) or close to zero (2014). }\end{array}$ & $\begin{array}{l}\text { Data on GDP growth of } \\
\text { Russian Federation from } \\
\text { WDI }\end{array}$ \\
\hline Border & $\begin{array}{l}\text { Dummy equals } 1 \text { for countries which border Russia. } \\
\text { Estonia, Latvia, Lithuania and Georgia are assigned } 0 \text { due } \\
\text { to existence of visa regime with Russia, despite having a } \\
\text { physical border. }\end{array}$ & $\begin{array}{l}\text { Visa policy of Russia: } \\
\text { http://www.russianvisa.org }\end{array}$ \\
\hline $\begin{array}{l}\text { The number of } \\
\text { service points of } \\
\text { MTOs in Russia }\end{array}$ & $\begin{array}{l}\text { Number of service points of MTOs implementing cross- } \\
\text { border transfers from Russia. }\end{array}$ & Central Bank of Russia \\
\hline $\begin{array}{l}\text { Bank branches per } \\
100,000 \text { adults }\end{array}$ & $\begin{array}{l}\text { Commercial bank branches are retail locations of resident } \\
\text { commercial banks and other resident banks that function } \\
\text { as commercial banks that provide financial services to } \\
\text { customers and are physically separated from the main } \\
\text { office but not organized as legally separate subsidiaries. }\end{array}$ & $\begin{array}{l}\text { Global Financial } \\
\text { Development Database, } \\
\text { World Bank }\end{array}$ \\
\hline $\begin{array}{l}\text { Three-bank } \\
\text { concentration ratio }\end{array}$ & $\begin{array}{l}\text { Assets of three largest commercial banks as a share of } \\
\text { total commercial banking assets. Total assets include total } \\
\text { earning assets, cash and due from banks, foreclosed real } \\
\text { estate, fixed assets, goodwill, other intangibles, current tax } \\
\text { assets, deferred tax assets, discontinued operations and } \\
\text { other assets. }\end{array}$ & Idem \\
\hline $\begin{array}{l}\text { The ratio of } \\
\text { transferable } \\
\text { deposits to GDP }\end{array}$ & $\begin{array}{l}\text { Deposit money banks' transferrable deposits expressed as } \\
\text { a percentage of GDP. Transferable deposits comprise all } \\
\text { deposits that are: (a) exchangeable on demand at par, } \\
\text { without penalty or restriction; (b) freely transferable by } \\
\text { cheque or giro-order; (c) otherwise commonly used to } \\
\text { make payments. }\end{array}$ & $\begin{array}{l}\text { International Financial } \\
\text { Statistics, IMF }\end{array}$ \\
\hline $\begin{array}{l}\text { ATMs per } 100,000 \\
\text { adults }\end{array}$ & $\begin{array}{l}\text { Automated teller machines are computerized } \\
\text { telecommunications devices that provide clients of a } \\
\text { financial institution with access to financial transactions in a } \\
\text { public place. }\end{array}$ & $\begin{array}{l}\text { Global Financial } \\
\text { Development Database, } \\
\text { World Bank }\end{array}$ \\
\hline Remittances & $\begin{array}{l}\text { Bilateral remittances for each of the countries of the former } \\
\text { Soviet Union implemented through MTOs for the period } \\
2006-2014 \text {. The bilateral remittance data for period } 2000 \text { - } \\
2005 \text { is estimated by Shelburne and Palacin (2007) based } \\
\text { on data on MTO remittances from Russia for } 2006 \text {. }\end{array}$ & $\begin{array}{l}\text { Central Bank of Russia and } \\
\text { Shelburne and Palacin } \\
\text { (2007) }\end{array}$ \\
\hline $\begin{array}{l}\text { Remittances per } \\
\text { capita }\end{array}$ & $\begin{array}{l}\text { Bilateral remittances for each of the countries of the former } \\
\text { Soviet Union divided by the population of each country. }\end{array}$ & Population data from WDI \\
\hline $\begin{array}{l}\text { Remittances to } \\
\text { GDP }\end{array}$ & $\begin{array}{l}\text { Bilateral remittances for each of the countries of the former } \\
\text { Soviet Union divided by the GDP of each country. }\end{array}$ & GDP data from WDI \\
\hline
\end{tabular}




\section{A2. Flow of Migrants to Russia}

The number of immigrants arriving in the Russian Federation who indicated the purpose of their visit as 'for work' (persons).

\begin{tabular}{lrrrrrrrrrrrrrrrr}
\hline & \multicolumn{10}{c}{ Year } \\
\hline $\begin{array}{l}\text { Country of } \\
\text { origin }\end{array}$ & 2000 & 2001 & 2002 & 2003 & 2004 & $\mathbf{2 0 0 5}$ & $\mathbf{2 0 0 6}$ & $\mathbf{2 0 0 7}$ & $\mathbf{2 0 0 8}$ & $\mathbf{2 0 0 9}$ & $\mathbf{2 0 1 0}$ & $\mathbf{2 0 1 1}$ & $\mathbf{2 0 1 2}$ & $\mathbf{2 0 1 3}$ \\
\hline Azerbaijan & 1799 & 729 & 461 & 186 & 124 & 196 & 1915 & 2934 & 2953 & 3211 & 2349 & 4781 & 5328 & 5876 \\
\hline Armenia & 1347 & 466 & 408 & 259 & 245 & 357 & 956 & 2282 & 2682 & 3154 & 1973 & 5032 & 6267 & 7805 \\
\hline Belarus & 775 & 455 & 440 & 335 & 322 & 326 & 311 & 366 & 365 & 314 & 286 & 2598 & 8114 & 6810 \\
\hline Georgia & 1148 & 438 & 253 & 216 & 252 & 185 & 203 & 422 & 380 & 357 & 234 & 448 & 527 & 525 \\
\hline Kazakhstan & 9829 & 4186 & 3093 & 1587 & 1670 & 2387 & 2249 & 1939 & 1891 & 2362 & 1517 & 2643 & 3544 & 4515 \\
\hline Kyrgyzstan & 1422 & 844 & 903 & 486 & 552 & 826 & 1349 & 4323 & 4644 & 4298 & 4474 & 11752 & 11079 & 10484 \\
\hline Latvia & 85 & 51 & 24 & 25 & 26 & 17 & 10 & 29 & 41 & 20 & 27 & 134 & 117 & 153 \\
\hline Lithuania & 43 & 38 & 31 & 27 & 11 & 9 & 12 & 17 & 16 & 19 & 15 & 57 & 41 & 72 \\
\hline Moldova & 1039 & 616 & 555 & 491 & 317 & 366 & 521 & 853 & 1030 & 1196 & 981 & 3282 & 4574 & 5917 \\
\hline Tajikistan & 1726 & 857 & 630 & 498 & 291 & 537 & 938 & 3356 & 4396 & 6722 & 5138 & 13060 & 18075 & 25383 \\
\hline Uzbekistan & 2308 & 1110 & 1094 & 805 & 512 & 743 & 2048 & 3646 & 2744 & 3997 & 3972 & 28854 & 46501 & 71738 \\
\hline Ukraine & 6233 & 2754 & 2406 & 1352 & 803 & 1060 & 1391 & 2330 & 1954 & 2247 & 1802 & 8615 & 11435 & 14283 \\
\hline Estonia & 41 & 21 & 25 & 19 & 27 & 22 & 13 & 27 & 48 & 44 & 46 & 279 & 239 & 281 \\
\hline
\end{tabular}

Source: Data is collected by the Federal Migration Service of the Russian Federation by statistical processing of arrival cards filled out by migrants upon their arrival at a registered address. As of 2011, these statistics take into account the migrants registered at the address for a period of nine months and longer. Before 2011, these migrants were not included in the statistics.

\section{A3. The average weighted cost of transfer of US\$200 from the Russian Federation over the period 2003-2013}

\begin{tabular}{lllllllllll}
\hline $\mathbf{2 0 0 3}$ & $\mathbf{2 0 0 4}$ & $\mathbf{2 0 0 5}$ & $\mathbf{2 0 0 6}$ & $\mathbf{2 0 0 7}$ & $\mathbf{2 0 0 8}$ & $\mathbf{2 0 0 9}$ & $\mathbf{2 0 1 0}$ & $\mathbf{2 0 1 1}$ & $\mathbf{2 0 1 2}$ & $\mathbf{2 0 1 3}$ \\
\hline $6.1 \%$ & $4.4 \%$ & $4.3 \%$ & $2.6 \%$ & $3.9 \%$ & $3.7 \%$ & $3.4 \%$ & $2.7 \%$ & $2.1 \%$ & $1.9 \%$ & $1.6 \%$
\end{tabular}

Source: Collected by the Central Bank of Russia in regular surveys of MTOs operating in Russia. 


\section{References}

Adams, R. H. (2009), 'The determinants of international remittances in developing countries', World Development, 37 (1), 93-103.

Aggarwal, R., Demirgüç-Kunt, A., Pería, M. S. M. (2011), 'Do remittances promote financial development?', Journal of Development Economics, 96 (2), 255-64.

Ahamada, I., Coulibaly, D. (2011), 'How does financial development influence the impact of remittances on growth volatility?', Economic Modelling, 28 (6), 2748-60.

Al Mamun, M., Sohag, K., Uddin, G. S., \& Shahbaz, M. (2015). 'Remittance and domestic labor productivity: Evidence from remittance recipient countries'. Economic Modelling, 47, 207218.

Akimov, A., Dollery, B. (2008), 'Financial policy in transition economies: architecture, pace, and sequencing', Problems of Economic Transition, 50 (9), 6-26.

Alkhathlan, K. A. (2013), 'The nexus between remittance outflows and growth: A study of Saudi Arabia', Economic Modelling, 33, 695-700.

Aslan, H. K. (2011), 'International Labor Migration from Rural Central Asia: The Potential for Development in Kyrgyzstan and Uzbekistan', Doctoral Dissertation, Kent State University, US.

Aydas, O. T., Metin-Ozcan, K., Neyapti, B. (2005), 'Determinants of workers' remittances: the case of Turkey', Emerging Markets Finance and Trade, 41 (3), 53-69.

Bang, J. T., Mitra, A., \& Wunnava, P. V. (2016). Do remittances improve income inequality? An instrumental variable quantile analysis of the Kenyan case. Economic Modelling 58, 394-402.

Buch, C. M., Kuckulenz, A. (2010), 'Worker remittances and capital flows to developing countries', International Migration, 48 (5), 89-117.

Central Bank of Russia (2009), 'Informatsionna-analyticheskiy material "Obzor rossiyskoga rynka denezhnyh perevodov za 2009 god"'. <http://www.cbr.ru/PSystem/Psys2/obzor_marketcard.pdf>, accessed 22 July 2015.

--- (2012), 'Obzor rynka platezhnyh uslug v Rossiyskoy Federatsii za 2011 god'. <http://www.cbr.ru/PSystem/analytics/Survey_2011.pdf>, accessed 22 July 2015.

Chowdhury, M. B. (2011), 'Remittances flow and financial development in Bangladesh', Economic Modelling, 28 (6), 2600-608.

Coulibaly, D. (2015). 'Remittances and financial development in Sub-Saharan African countries: A system approach'. Economic Modelling, 45, 249-258.

Cox, D., Jakubson, G. (1995), 'The connection between public transfers and private interfamily transfers', Journal of Public Economics, 57 (1), 129-67.

Cragg, J. G., Donald, S. G. (1993), 'Testing identifiability and specification in instrumental variable models', Econometric Theory, 9 (2), 222-40.

Durand, J., Kandel, W., Parrado, E. A., Massey, D. S. (1996), 'International migration and development in Mexican communities', Demography, 33 (2), 249-64.

Freund, C., Spatafora, N. (2008), 'Remittances, transaction costs, and informality', Journal of Development Economics, 86 (2), 356-66.

Hansen, L. P. (1982), 'Large sample properties of generalized method of moments estimators', Econometrica: Journal of the Econometric Society, 50 (4), 1029-54.

Hathroubi, S., and Chaker, A. (2016) 'On interactions between remittance outflows and Saudi Arabian macroeconomy: New evidence from wavelets'. Economic Modelling, 59, 32-45.

International Monetary Fund (2005), 'World Economic Outlook, April 2005: Globalization and External Imbalances', in World Economic and Financial Surveys (Washington DC: International Monetary Fund).

Juraev, A. (2012), 'Labor Migration from Uzbekistan: Social and Economic Impacts on Local Development', Doctoral Dissertation, University of Trento, Italy.

Kakhkharov, J., Akimov, A. (2015), 'Estimating remittances in the former Soviet Union: Methodological complexities and potential solutions', in R. Jamilov, Y. H. Akbar (eds), NeoTransitional Economics (Bingley, UK: Emerald Group), 337-62. 
Kleibergen, F., Paap, R. (2006), 'Generalized reduced rank tests using the singular value decomposition', Journal of Econometrics, 133 (1), 97-126.

Lucas, R. E. B., Stark, O. (1985), 'Motivations to remit: Evidence from Botswana', The Journal of Political Economy, 93 (5), 901-18.

Lueth, E., Ruiz-Arranz, M. (2008), 'Determinants of bilateral remittance flows', Topics in Macroeconomics, 8 (1), 1568.

Makaryan, S. (2015), 'Estimation of International Migration in Post-Soviet Republics', International Migration, 53 (5), 26-46.

Makhmutova, M., Makatova, A., Kourmanova, A., Abdullaev, U., Dienova, M., Bakas Ulu, B. (2008), 'Country Report on Remittances of International Migrants and the Financial Sector in Kazakhstan', Study on International Migrants' Remittances in Central Asia and South Caucasus (Manila: Asian Development Bank).

Orozco, M. (2006), 'International Flows of Remittances: Cost, competition and financial access in Latin America and the Caribbean-toward an industry scorecard', (Washington, DC: InterAmerican Dialogue).

Piracha, M., Saraogi, A. (2012), 'The Determinants of Remittances: Evidence from Moldova', Oxford Development Studies, 40 (4), 467-91.

Rapoport, H., Docquier, F. (2006), 'The economics of migrants' remittances', in Handbook on the Economics of Giving, Altruism and Reciprocity, Vol 2, 1135-98.

Sayan, S. (2006), 'Business cycles and workers' remittances: How do migrant workers respond to cyclical movements of GDP at home?', IMF Working Paper No. 06/52.

Schiopu, I. C., Siegfried, N. (2006), 'Determinants of Workers' Remittances: Evidence from the European Neighbouring Region', ECB Working Paper No. 688.

Schrooten, M. (2005), 'Bringing Home the Money-What Determines Worker's Remittances to Transition Countries', Institute of Economic Research, Hitotsubashi University, Discussion Paper Series A No. 466.

--- (2006), 'Workers' remittances to former Soviet States', Institute of Economic Research, Hitotsubashi University, Discussion Paper Series A No. 476.

Shelburne, R. C., Palacin, J. (2007), 'Remittances in the CIS: Their economic implications and a new estimation procedure', Discussion Paper Series No. 2007.5 (Geneva: United Nations Economic Commission for Europe).

Singh, R. J., Haacker, M., Lee, K. W., Le Goff, M. (2010), 'Determinants and macroeconomic impact of remittances in Sub-Saharan Africa', Journal of African Economies, 20 (2), 312-40.

Stark, O. (1991), The Migration of Labor (Cambridge, MA: Basil Blackwell).

--- (1996), On the Microeconomics of Return Migration (Vienna: Universität Wien).

Straubhaar, T. (1986), 'The determinants of workers' remittances: The case of Turkey', Review of World Economics, 122 (4), 728-40.

World Bank (2014), 'Annual Remittance Data', in Remittance Data (Washington, DC: World Bank). 